\title{
ANALISIS KEBUTUHAN PENGEMBANGAN BAHAN AJAR SISTEM REKAYA TV BERBASIS E MODUL DI JURUSAN PENDIDIKAN TEKNIK ELEKTRONIKA UNIVERSITAS NEGERI MAKASSAR
}

\author{
Mahmud Mustapa ${ }^{1}$, Ummiati Rahmah ${ }^{2}$ \\ 1,2 Jurusan Pendidikan Teknik Elektronika FT UNM \\ Ie-mail: mahmud.mustapa@unm.co.id, ${ }^{2}$ e-mail: ummiati.rahmah@unm.co.id
}

\begin{abstract}
Abstrak
Tujuan penelitian ini adalah untuk mendeskripsikan persepsi mahasiswa dan dosen terhadap Pengembangan bahan ajar Sistem Rekayasa TV berbasis digital Modul, serta membandingkan persepsi antara mahasiswa dan dosen terhadap Pengembangan bahan ajar Sistem Rekayasa TV berbasis digital Modul. Jenis penelitian ini adalah jenis penelitian expos facto dimana peneliti melakukan pengumpulkan data secara langsung kepada responden melalui instrument pengumpulan data. Data diperoleh melalui wawancara, angket, dan observasi. Teknik analisis data dilakukan dengan cara deskriptif kuantitatif. Hasil penelitian ditemukan bahwa mahasiswa pada kategori sangat membutuhkan sebanyak 14 orang atau 35\%, Dibutuhkan 13 orang (32.5\%) dan pada kategori cukup juga sebanyak 13 orang (32.5\%) sedangkan Dosen pada kategori sangat dibutuhkan sebanyak 2 orang atau 10\%, Dibutuhkan 12 orang (60\%) dan pada kategori cukup sebanyak 6 orang (30\%). Hasil uji hipotesis ditemukan bahwa tidak ada perbedaan pandangan antara mahasiswa dengan pandangan dosen terkait kebutuhan perangkat pembelajaran bahan ajar Sistem Rekayasa TV Berbasis E Mudol bahwa sama-sama sepakat bahwa memang sangat dibutuhkan.
\end{abstract}

Kata kunci : Analisis kebutuhan, modul digital, Sistem Rekayasa TV

\begin{abstract}
The purpose of this study was to describe the perceptions of students and lecturers towards the development of Module-based digital TV Engineering System teaching materials, as well as comparing perceptions between students and lecturers towards the development of Module-based digital TV Engineering Systems teaching materials. This type of research is a type of expos facto research in which researchers collect data directly to respondents through data collection instruments. Data obtained through interviews, questionnaires, and observations. The data analysis technique is done by quantitative descriptive method. The results of the study found that students in the category really needed as many as 14 people or $35 \%, 13$ people needed $(32.5 \%)$ and in the enough categories also as many as 13 people (32.5\%) while Lecturers in the category of very much needed were 2 people or $10 \%$, needed 12 people $(60 \%)$ and in the category enough as many as 6 people (30\%). The results of the hypothesis test found that there were no differences in views between students and the views of lecturers related to the need for learning tools for teaching materials for the E-Mudol-based TV Engineering System that both agreed that it was really needed.
\end{abstract}

Keywords: Requirement analysis, digital modules, TV Engineering Systems

PENDAHULUAN

Salah satu cara agar supaya para alumni UNM dapat bersaing untuk memenuhi lapangan kerja yang dibutuhkan bangsa ini adalah dengan meningkatkan kualitas belajar mahasiswa. Kualitas belajar ini dapat ditingkatkan dengan memberikan pembelajaran yang cenderung bersifat 
simulasi yang sesuai dengan kebutuhan lapangan kerja.

Pendidikan mempunyai peranan sangat penting dalam menentukan daya saing bangsa, sehingga sektor pendidikan harus terus menerus ditingkatkan mutunya. Namun hingga saat ini kesenjangan pelaksanaan pendidikan masih terkendala oleh banyak faktor. Diantara faktor-faktor tersebut adalah masih adanya kesenjangan mutu antara setiap penyelenggara pendidikan.

Berdasarkan hasil observasi ditambah pengalaman peneliti selama hampir 20 tahun mengajar mata kuliah teknik Bahan ajar Sistem Rekayasa TV Berbasis E Mulodteridentifikasi berbagai masalah yang umumnya bersumber dari tiga (3) sumber utama pembelajaran yaitu: a) kemampuan dosen, b) kemampuan mahasiswa, dan c) keterbatasan peralatan. Kemampuan dosen sangat terkait dengan kompetensi mengajar dosen baik yang menyangkut kompetensi/penguasaan substansi bidang maupun kompetensi/penguasaan penyampaian materi pengajaran (strategi pembelajaran).

Kemampuan mahasiswa terkait oleh kemampuan awal mahasiswa, kreativitas mahasiswa, dan motivasi mahasiswa, sedangkan keterbatasan peralatan menyangkut ketersediaan peralatan praktikum baik dari sisi kualitas, maupun kuantitasnya, termasuk rasio antara mahasiswa dan peralatan yang ada.

Kekurang-optimalan dari ketiga sumber di atas akan menyebabkan tidak efisien dan efektifnya proses belajar mengajar. Namun demikian dari tiga sumber permasalahan dan banyak aspek yang dapat mempengaruhi keberhasilan proses belajar mengajar, pada penelitian ini hanya akan difokuskan atau disempitkan permasalahan pada kemampuan dosen, khususnya dalam mengembangkan strategi pembelajaran yang dapat meningkatkan efisiensi dan efektivitas pragram pembelajaran, yang pada akhirnya dapat meningkatkan kualitas mahasiswa, kreativitas, dan kemandirian mahasiswa.

$\begin{array}{lcr}\quad \text { Salah } & \text { satu cara } & \text { untuk } \\ \text { menumbuhkan } & \text { kreativitas } & \text { dalam } \\ \text { pembelajaran } & \text { adalah } & \text { dengan }\end{array}$
menggunakan banyak ragam media (audio, visual, animasi gerak dan lainlain) maka akan menghasilkan proses kognitif yang maksimal. Dengan bahasa sederhana dikatakan bahwa terdapat kekeliruan pandangan dengan memberikan banyak hal (teks, gambar, animasi dan sebagainya) maka peserta didik dalam hal ini mahasiswa mendapat lebih banyak informasi.

$\begin{array}{ccc}\text { Pembelajaran } & \begin{array}{c}\text { dengan banyak } \\ \text { dengan nama }\end{array}\end{array}$ pembelajaran berbasis multimedia. Multimedia sebagai sarana pendidikan memiliki setidaknya dua pengertian yaitu gabungan dari berbagai macam media (bahan cetak/teks, audio, video, Slide, siaran radio, siaran televisi) yang masingmasing berdiri sendiri namun terprogram. Banyak strategi dan cara yang dapat ditempuh untuk mencapai tujuan pembelajaran yang maksimal yaitu dengan peningkatan kualitas dan profesionalisme dosen, manajemen kampus yang baik, pengadaan fasilitas praktikum yang lengkap, pembelajaran yang bermakna, penyempurnaan kurikulum dan lain sebagainya. Namun kadangkala ada faktor yang tidak terpenuhi secara maksimal, baik dalam hal pengelolaan dalam cakupan yang lebih besar, maupun dalam pembelajaran yang lebih kecil, yaitu pembelajaran di kelas.

Salah satu cara untuk mengatasi masalah tersebut adalah dengan penggunaan suatu model pembelajaran yang efektif seperti pembelajaran dengan mengunakan Multimedia. Untuk mengambarkan tahapan dan cara kerja dari materi yang harus dikuasai mahasiswa, dosen seringkali mengalami kesulitan. Khususnya dalam praktek, hal ini disebabkan karena setelah 
menjelaskan seorang dosen harus berkeliling untuk menjelaskan dari satu mahasiswa ke mahasiswa yang lain. Materi itupun perlu diulang karena jika mahasiswa belum paham, maka mahasiswa harus diberi penjelasan secara berulang-ulang, sehingga membuat proses perkuliahan dan praktek menjadi tidak optimal.

Suparman (2004) mengemukakan bahwa, pengembangan pembelajaran lebih menitik beratkan pada tujuan yaitu memecahkan masalah belajar, meningkatkan kualitas kegiatan pembelajaran, atau menciptakan situasi kondisi belajar yang memungkinkan peserta didik berinteraksi sehingga terjadi perubahan perilaku melalui suatu proses melalui desain, produksi, dan evaluasi. Prosesnya dimulai dengan mengidentifikasi masalah, mengembangkan strategi dan bahan pembelajaran diakhiri dengan mengevaluasi efektifitas dan efisiensi.

Untuk melihat tingkat kelayakan suatu model pengembangan pembelajaran pada aspek validitas dibutuhkan ahli dan praktisi untuk memvalidasi model pengembangan pembelajaran yang dikembangkan. Sedangkan untuk aspek kepratisan dan efektifitas diperlukan suatu perangkat pembelajaran untuk melaksanakan model pembelajaran yang dikembangkan. Dengan demikian, untuk melihat kedua asfek ini perlu dikembangkan suatu perangkat pembelajaran dan dikembangkan pula instrument penelitian sesuai dengan yang diinginkan.

Model pengembangan pembelajaran berfungsi mengarahkan untuk menyelesaikan pembelajaran yang digunakan sebagai pedoman dalam penyelenggaraan pembelajaran agar tercapai pembelajaran yang efektif, efisien, berdaya guna, menarik, dan humanis. Selain itu berfungsi sebagai alat berkomunikasi dan petunjuk dalam perencanaan aktifitas yang akan dilaksanakan pada pengelolaan dan pengambilan keputusan.

Hal ini semakin mempertegas beberapa uraian di atas tentang peranannya dalam pembelajaran. Keuntungan pemanfaatan multimedia dalam pembelajaran sejalan dengan apa yang dikemukanan Roblyer (2000) antara lain adalah:

1. Lahirnya motivasi yang dapat meningkatkan perhatian siswa, melibatkan siswa dalam menghasilkan pekerjaan dan meningkatkan kontrol belajar.

2. Kapabilitas pengajaran (instruksional) yang unik yang dapat meghubungkan siswa pada sumber informasi, menolong siswa memvisualisasikan masalah dan persoalan, pelacakan perkembangan belajar, menghubungkan siswa pada learning tools.

3. Dukungan terhadap pendekatan pengajaran baru yaitu cooperatif, share intelegence, problem solving, dan kecakapan intelektual tingkat tinggi.

4. Peningkatan produktivitas pengajar di mana pengajar memiliki waktu luang untuk membantu siswa/mahasiswa selama pembelajaran (sebagai fasilitator), menyediakan informasi yang lebih akurat dan cepat, memberi kesempatan pengajar untuk memproduksi bahan pembelajaran menjadi lebih menarik dan studentfriendly secara cepat.

5. Membantu melatih kecakapan yang dibutuhkan dalam era teknologi informasi antara lain untuk melek teknologi, informasi dan visual.

\section{Penggunaan Teknologi} multimedia dapat menciptakan suatu media pembelajaran dengan kombinasi teks, gambar, seni grafik, animasi, suara, dan video. Aneka media tersebut ketika digabungkan menjadi satu kesatuan kerja akan menghasilkan suatu informasi 
dengan nilai komunikasi yang sangat tinggi. Sehingga memberikan rangsangan dan stimulus yang kuat bagi mahasiswa untuk terus belajar (Oetomo, 2002:109).

Menurut Smaldino, Lowther, dan Russell (2008), bahwa pembelajaran yang dirancang baik diawali dengan timbulnya minat peserta didik atau warga belajar dan kemudian berlanjut pada penyajian material baru, melibatkan peserta didik dalam praktik dengan umpan balik, menilai pemahaman peserta didik, dan memberikan kegiatan tindak lanjut yang relevan.

Ramsden (2003) memaparkan beberapa kunci pembelajaran di perguruan tinggi agar menjadi efektif, antara lain; (1) Ketertarikan mahasiswa terhadap pembelajaran, (2) Apresiasi dan respek terhadap mahasiswa dan cara belajarnya, (3) Ketepatan melakukan asesmen dan umpan balik, (4) Kejelasan tujuan dan minat pada tantangan intelektual, (5) Kemandirian dan (6) Pengendalian dan pengembangan diri secara aktif.

Strategi pembelajaran dengan menggunakan multimedia untuk meningkatkan hasil belajar mahasiswa di jurusan Pendidikan Teknik Elektronika Fakultas Teknik Universitas Negeri Makassar saat ini mungkin perlu dilakukan. Hal ini berdasarkan hasil penelitian dan hasil observasi yang dilakukan dua tahun terakhir teridentifikasi berbagai kendala dalam pelaksanaan perkuliahan di jurusan Teknik Elektronika, khususnya pada pelaksanaan banyak mata kuliah praktikum seperti: Teknik Telekomunikasi, Elektronika I, Elektronika II, Teknik dasar Listrik, Teknik Audio video, Mikroprosessor dan elektronika lanjut (rancang bangun).

Gerlach dan Ely (1979: 241) mendefenisikan, secara umum media dapat dipahami sebagai segala sesuatu, benda, atau bahkan lingkungan sekolah yang memungkinkan pelajar untuk memperoleh pengetahuan, sikap, dan keterampilan. Dalam hal ini, Dosen, buku, dan lingkungan sekolah dapat dipahami sebagai media. Secara lebih khusus pengertian media dalam proses belajar mengajar cenderung diartikan sebagai alat-alat grafis, photografis, atau alat-alat elektronik untuk menangkap, memproses, menyusun kembali informasi visual atau verbal.

Robin dan Linda (2001) menyebutkan multimedia sebagai alas yang dapat menciptakan presentasi yang dinamis dan interaktif yang mengombinasikan teks, grafik, animasi, audio, dan video. Dalam konteks komunikasi pembelajaran, Hofstetter (2001) menyebutkan bahwa multimedia dapat dipandang sebagai suatu pemanfaatan komputer untuk membuat dan menggabungkan teks, grafik, audio, gambar bergerak (video dan animasi) dengan menggabungkan link dan toot yang memungkinkan pemakai untuk melakukan navigasi, berinteraksi, berkreasi, dan berkomunikasi.

Dalam konteks pembelajaran multimedia telah mampu memberikan berbagai ciri dan prinsip sehingga sebuah pembelajaran dapat dikatakan menggunakan multimedia, jika di dalamnya memiliki karakteristik sebagai berikut: (1) Content Representation; (2) Full Color and High Resolution; (3) Melalui media elektronik; (4) Tipe-tipe pembelajaran yang bervariasi; (5) Respons Pembelajaran dan Penguatan; (6) Mengembangkan prinsip Self Evaluation; (7) Dapat digunakan secara klasikal atau individual.

Dani (2011: 45) menjelaskan bahwa dalam pengembangan sebuah multimedia pembelajaran dibutuhkan beberapa tahapan seperti: Penulisan Story Board, Pengumpulan Bahan Grafis, Pengumpulan Bahan Animasi, Pemrograman, Finishing Mastering.

Story board pada dasarnya merupakan pengembangan dari flow chart. Flow chart hanya berisi garis besar pada setiap alur dari awal sampai selesai, 
dan story board merupakan penjelasan lebih lengkap dari setiap alur yang terdapat pada flow chart. Fungsi story board, di antaranya: (1) Sebagai media yang memberikan penjelasan secara lebih lengkap apa yang terdapat pada setiap alur di dalam flow chart. (2) Sebagai pedoman bagi programmer dan animator dalam merealisasikan rencana program ke dalam bentuk bahasa program dan animasi. (3) Sebagai pedoman bagi pengisi suara (narrator) dan teknisi rekaman dalam merekam suara untuk kebutuhan naskah. (4) Sebagai dokumen tertulis.

Apabila ada pihak yang menginginkan data tertulis (naskah) dari program yang sudah dibuat, maka dapat story board. (5) Sebagai bahan dalam pembuatan manual book. Setiap program yang telah dibuat, sebaiknya dibuatkan manual book yang berfungsi sebagai buku petunjuk penggunaan dan isi program. Pembuatan manual book merujuk pada story board yang ada. Hal ini juga diperlukan apabila program akan dibuat hak paten yang mempersyaratkan story board dan manual book.

Kemudian untuk Pengumpulan bahan grafis merupakan sebuah program MMI tidak terlepas dari unsur grafis. Dalam hal ini grafis berfungsi untuk memperjelas informasi, memperindah tampilan, serta membuat program menjadi lebih hidup dengan berbagai kombinasi warna dan objek dapat berupa foto, kartun/ilustrasi gambar, rekayasa foto, dan penggunaan teks. Sebelum mulai menyusun program, bahan-bahan grafis yang dibutuhkan sesuai dengan tuntunan story board perlu disiapkan terlebih dahulu. Dalam pembuatannya diperlukan software khusus berupa pengolahan vektor dan bitmap, misalnya corel photoshop.

Selain itu Pengumpulan Bahan Animasi yang digunakan untuk menjelaskan pesan yang membutuhkan unsur gerak (movie), membuat tampilan lebih hidup dan menarik perhatian. Animasi dapat dibuat dengan menggunakan software 3D Max, Flash, dan swish. Selanjutnya tahap utama dalam membuat pembelajaran interaktif adalah pemrograman yang pada dasarnya menggabungkan berbagai bahan grafis, animasi, dan teks yang disusun berdasarkan alur yang sesuai dengan flow chart. Software yang dapat digunakan untuk pemrograman diantaranya: Delphi, Basic, Pascal, Authorware, Macromedia Flash, Swish, Director. Tahap finishing merupakan tahap akhir dalam pembuatan program. Program dibuat menjadi file aplikasi (exe), html, atau movie show.

Model Borg \& Gall (2003: 570), secara rinci model penelitian ini memiliki sepuluh langkah pelaksanaan penelitian sebagai berikut; (1) penelitian dan pengumpulan data awal. Pada tahap ini dilakukan penelitian dalam skala kecil, observasi dan identifikasi perkiraan kebutuhan mengenai permasalahan yang ada di Perguruan Tinggi mengenai pelaksanaan kegiatan praktikum elektronika bahan ajar Sistem Rekayasa TV,serta mempelajari literatur; (2) perencanaan, dalam perencanaan dan merumuskan tujuan penelitianperlu diperkirakan waktu yang diperlukan untuk pembuatan produk, prosedur, kerja penelitian dan berbagai bentuk partisipasi kegiatan selama penelitian termasuk uji coba skala kecil.

Hal inilah yang menyebabkan penulis merasa perlu dan terdorong melakukan penelitian terkait dengan analisis kebutuhan perkuliahan yang berbantukan multimedia pembelajaran sehungga tujuan dari penelitian ini adalah:

1. Mengetahui bagaimana persepsi mahasiswa dan dosen terhadap bahan ajar bahan ajar Sistem Rekayasa TV?

2. Membandingkan persepsi antara mahasiswa dan dosen terhadap bahan ajar bahan ajar Sistem Rekayasa TV? 


\section{METODE PENELITIAN}

Jenis Penelitian ini adalah penelitian expos facto dimana peneliti melakukan pengumpulkan data secara langsung kepada responden melalui instrument pengumpulan data. Penelitian ini di lakukan pada Jurusan pendidikan Teknik Elektronika. Proses pengumpulan data merupakan tahapan dalam penelitian yang sangat penting. Data yang akan dikumpulkan nantinya akan digunakan untuk menguji hipotesis yang diajukan dalam penelitian diman Data diperoleh melalui wawancara, angket, dan observasi. Teknik analisis data dilakukan dengan cara deskriptif kuantitatif.

\section{HASIL DAN PEMBAHASAN}

Pelaksanaan penelitian ini dilakukan sesuai dengan jadwal yang telah ditentukan sebelumnya dengan dengan terlebih dahulu merancang instrument penelitian yang dapat digunakan dalam mengumpulkan informasi dari responden yang akan menjadi sumber informasi.

Instrumen penelitian sebelum digunakan sebaiknya harus melalui tahap validasi pakar untuk mengukur kualitas instrument tersebut sebelum digunakan, karena instrument yang baik maka akan menghasilkan informasi yang baik pula, begitupun sebaliknya. Untuk itu, instrument yang akan digunakan dalam pengumpulan data minimal dinilai oleh ahli yang biasa disebut dengan validator ahli. Data validasi ahli terdiri dari tiga kelompok yaitu 2(dua) ahli materi, 2(dua) ahli media dan 2 (dua) orang ahli desain. Data yang diperoleh dari hasil penelitian, saran dan komentar dari para ahli dijadikan sebagai bahan dalam merevisi instrument.

Berdasarkan hasil analisis ditemukan tingkat kesepakatan (reliabilitas) rater dalam memberikan penilaian dapat dijelaskan dengan menghitung rata-rata koefisien reliabilitas antar penilai menggunakan koefisien Cohen's Kappa (K) dan hasilnya dibandingkan dengan kriteria minimal reliabilitas.

Berdasarkan hasil analisis kesepakatan antar rater tampak bahwa nilai yang dihasilkan untuk instrument ahli media sebesar 0.82 , instrument untuk ahli media sebesar 0.75 sedangkan instrument ahli desain ditemukan hasil analisis sebesar 0.773. Melihat nilai tingkat kesepakatan diantara para penilai lebih besar dari standar yang telah ditentukan yaitu sebesar 0.70 menurut Linn (Mansyur, 2010), sehingga instrumen tersebut memenuhi syarat kriteria reliabel.

Selanjutnya, analisis antar rater dilakukan maka selanjutnya dilakukan analisis kebutuhan para mahasiswa dalam mendesain sistem pembelajaran dilakukan dengan mengajukan pertanyaan dari lima indikator, yaitu: 1) kondisi strategi pembelajaran; 2) kondisi penggunaan bahan pembelajaran; 3) kondisi sarana belajar; 4) kondisi kompetensi dosen; 5) kondisi karakteristik mahasiswa; Kelima indikator tersebut dijabarkan ke dalam 56 pertanyaan. Hasil penyebaran kuesioner analisis kebutuhan dapat dilihat berdasarkan criteria seperti berikut:

Tabel 1. Kriteria kebutuhan

\begin{tabular}{|c|c|}
\hline Rerata Skor & \multicolumn{2}{|c|}{ Kriteria } \\
\hline Sangat dibutuhkan & $>42.75$ \\
\hline Dibutuhkan & $28.6-42.75$ \\
\hline Cukup & $14.26-28.5$ \\
\hline Tidak dibutuhkan & $\leq 14.25$ \\
\hline
\end{tabular}

Berdasarkan criteria kebutuhan pada Tabel 1. yang merupakan dasar pengambilan keputusan apakah perangkat bahan ajar berbasis multimedia dibutuhkan oleh masiswa atau tidak dan criteria tersebut juga menjadi dasar pengambilan keputusan untuk melihat bahwa respon dosen. Hasil analisis untuk data mahasiswa dapat dilihat pada Tabel 2. 
Tabel 2.

Hasil Analisis Kebutuhan pandangan

mahasiswa

\begin{tabular}{|l|r|r|r|r|}
\hline & $\begin{array}{c}\text { Freq } \\
\text { uenc } \\
\mathrm{y}\end{array}$ & $\begin{array}{c}\text { Perce } \\
\mathrm{nt}\end{array}$ & $\begin{array}{c}\text { Valid } \\
\text { Perce } \\
\text { nt }\end{array}$ & $\begin{array}{c}\text { Cumulati } \\
\text { ve } \\
\text { Percent }\end{array}$ \\
\hline Cukup & 13 & 32.5 & 32.5 & 32.5 \\
\hline Dibutuhkan & 13 & 32.5 & 32.5 & 65.0 \\
\hline $\begin{array}{l}\text { Sangat } \\
\text { dibutuhkan }\end{array}$ & 14 & 35.0 & 35.0 & 100.0 \\
\hline Total & 40 & 100.0 & 100.0 & \\
\hline
\end{tabular}

Berdasarkan tabel analisis diatas menunjukkan bahwa jumlah mahasiswa pada kategori sangat membutuhkan sebanyak 14 orang atau 35\%, Dibutuhkan 13 orang $(32.5 \%)$ dan pada kategori cukup juga sebanyak 13 orang (32.5\%), untuk melengkapi hasil analisis tersebut dapat dilihat grafik seperti berikut:

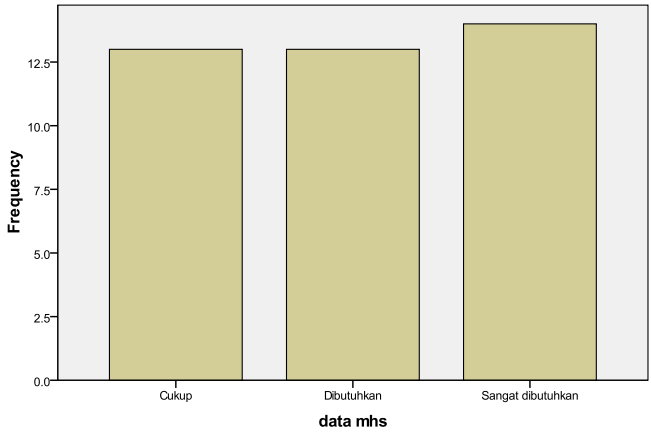

Gambar 1. Hasil Analisis Kebutuhan pandangan mahasiswa

Selanjutnya, hasil analisis berdasarkan kebutuhan berdasarkan pandangan oleh dosen pada jurusan pendidikan teknik elektronika yang juga merupakan dasar pengambilan keputusan apakah perangkat bahan ajar berbasis multimedia dubutuhkan atau tidak pada jurusan pendidikan teknik elektrnika dan hasil analisis dapat dilihat seperti pada Tabel 2.

Tabel 2.

Hasil Analisis Kebutuhan pandangan

Dosen

\begin{tabular}{|l|r|r|r|r|}
\hline & $\begin{array}{c}\text { Frequ } \\
\text { ency }\end{array}$ & $\begin{array}{c}\text { Per } \\
\text { cent }\end{array}$ & $\begin{array}{c}\text { Valid } \\
\text { Perce } \\
\text { nt }\end{array}$ & $\begin{array}{c}\text { Cumulati } \\
\text { ve } \\
\text { Percent }\end{array}$ \\
\hline Cukup & 6 & 30.0 & 30.0 & 30.0 \\
\hline Dibutuhkan & 12 & 60.0 & 60.0 & 90.0 \\
\hline $\begin{array}{l}\text { Sangat } \\
\text { dibutuhkan }\end{array}$ & 2 & 10.0 & 10.0 & 100.0 \\
\hline
\end{tabular}

\begin{tabular}{|l|r|r|r|l|}
\hline Total & 20 & 100. & 100.0 & \\
& & 0 & & \\
\hline
\end{tabular}

Berdasarkan tabel analisis diatas menunjukkan bahwa jumlah dosen pada kategori sangat dibutuhkan sebanyak 2 orang atau 10\%, Dibutuhkan 12 orang (60\%) dan pada kategori cukup sebanyak 6 orang (30\%), untuk melengkapi hasil analisis tersebut dapat dilihat grafik seperti berikut:

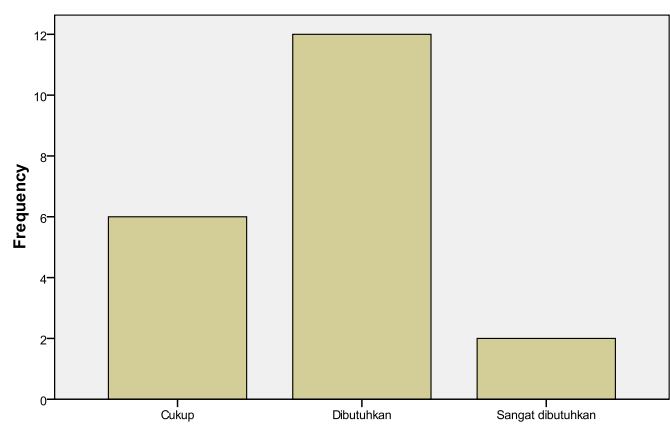

Gambar 2.

Hasil Analisis Kebutuhan pandangan Dosen

Setelah analisis dekriptif terkait analisis kebutuhan menurut pandangan mahasiswa dan dosen, selanjutnya dilakukan analisis komparatif yang bertujuan untuk melihat perbedaan pandangan mahasiswa dengan dosen terhadap perangkat pembelajaran bahan ajar Sistem Rekayasa TV namun sebelumnya data harus melalui uji normal.

\section{Uji Normal}

Dimana uji Normalitas bertujuan untuk mengetahui apakah sebaran data responden berdistribusi normal ataukah tidak. Ada beberapa cara yang dapat digunakan dalm menguji normal suatu data diantaranya menggunakan metode Kolmogorof Smirnov (K-S).

Uji Kolmogorov Smirnov adalah pengujian normalitas yang banyak dipakai, terutama setelah adanya banyak program statistic yang beredar.dengan kriteria jika nilai signifikansi (Asym Sig) $>0,05$, maka data tersebut berdistribusi normal. Jika nilai signifikansi (Asym Sig) 
$<0,05$, maka data tersebut tidak berdistribusi normal dan hasil analisis dapat dilhat pada Tabel 3 dan Tabel 4.

Tabel 3.

Hasil uji normal data Dosen

\begin{tabular}{|c|c|}
\hline & Dosen \\
\hline 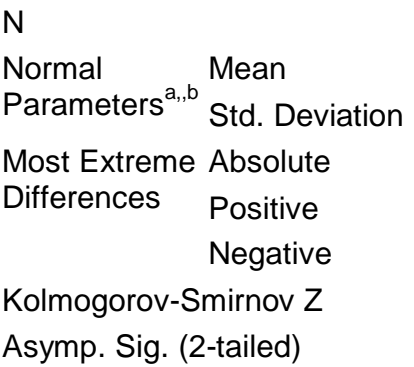 & $\begin{array}{r}20 \\
32.8000 \\
7.80418 \\
.159 \\
.117 \\
-.159 \\
.712 \\
.691\end{array}$ \\
\hline
\end{tabular}

a. Test distribution is Normal.

b. Calculated from data.

Berdasarkan hasil uji normalitas Kolmogorof Smirnov (K-S) pada Tabel 3. terlihat bahwa nilai signifikansi Asym Sig > 0,05 $(0,691>0,05)$ maka data tersebut berdistribusi normal sedangkan uji normal untuk data Mahasiswa dapat dilihat pada Tabel 4.

Tabel 4.

Hasil uji normal data Mahasiswa Mahasiswa

\begin{tabular}{|c|c|c|}
\hline & & Mahasiswa \\
\hline \multicolumn{2}{|l|}{$\mathrm{N}$} & 40 \\
\hline \multirow{2}{*}{$\begin{array}{l}\text { Normal } \\
\text { Parameters }\end{array}$} & Mean & 34.0500 \\
\hline & Std. Deviation & 9.59420 \\
\hline \multirow{3}{*}{$\begin{array}{l}\text { Most Extreme } \\
\text { Differences }\end{array}$} & Absolute & .182 \\
\hline & Positive & .150 \\
\hline & Negative & -.182 \\
\hline \multicolumn{2}{|c|}{ Kolmogorov-Smirnov Z } & 1.154 \\
\hline \multicolumn{2}{|c|}{ Asymp. Sig. (2-tailed) } & .140 \\
\hline
\end{tabular}

a. Test distribution is Normal.

b. Calculated from data.

Merujuk pada tabel 4. Tampak bahwa data tersebut juga memenuhi kriteria Normal karena hasil analisis Kolmogorof Smirnov (K-S) pada tabel tersebut terlihat nilai signifikansi Asym
Sig > 0,05 $(0,140>0,05)$ maka data tersebut berdistribusi normal.

\section{Uji Homogen}

Uji homogenitas digunakan untuk mengetahui apakah kelompok responden berasal dari populasi yang sama atau tidak. Dengan menggunakan SPSS peneliti dapat dilakukan perhitungan test of homogeneity of variance.

Tabel 5. Uji Homogenitas

analisis_kebutuhan

\begin{tabular}{|r|r|r|l|}
\hline Levene Statistic & df1 & df2 & \multicolumn{1}{l|}{ Sig. } \\
\hline 2.302 & 1 & 58 & .135 \\
\hline
\end{tabular}

Berdasarkan hasil analisis diatas dapat dilihat pada output test of homogeneity of variance. Dari output dapat diketahui bahwa nilai signifikansi (sig) sebesar 0,135 . Karena signifikansi lebih besar dari alfa 0,05, maka dapat disimpulkan bahwa kedua data mempunyai varian sama (homogen).

\section{Uji T}

Kriteria pengambilan keputusan

- Jika $\mathrm{t}$ hitung $\geq \mathrm{t}$ tabel, maka tolak $\mathrm{H} 0$ artinya ada perbedaan.

- Jika t hitung < tabel, maka terima $\mathrm{H} 0$ artinya tidak ada perbedaan.

\section{Hipotesis}

- Ha: Ada perbedaan persepsi mahasiswa dengan Dosen.

- Ho: Tidak ada perbedaan persepsimahasiswa dengan dosen

Dengan kriteria dan hipotesis yang telah disajikan sebelumnya merupakan panduan dalam pengambilan keputusan hasil analisis apakah terdapat perbedaan persepsi antara mahasiswa dengan dosen dan hasil analisis dapat dilihat pada Tabel 6. 
Tabel 6. Hasil analisis Komparatif

\begin{tabular}{|c|c|c|c|c|c|c|c|c|c|c|}
\hline & \multicolumn{2}{|c|}{$\begin{array}{l}\text { Levene's Test } \\
\text { for Equality of } \\
\text { Variances }\end{array}$} & \multicolumn{7}{|c|}{ t-test for Equality of Means } \\
\hline & & \multirow[b]{2}{*}{$\mathrm{F}$} & \multirow[b]{2}{*}{ Sig. } & \multirow[b]{2}{*}{$\mathrm{T}$} & \multirow[b]{2}{*}{ Df } & \multirow[b]{2}{*}{$\begin{array}{l}\text { Sig. (2- } \\
\text { tailed) }\end{array}$} & \multirow[b]{2}{*}{$\begin{array}{c}\text { Mean } \\
\text { Difference }\end{array}$} & \multirow[b]{2}{*}{$\begin{array}{l}\text { Std. Error } \\
\text { Difference }\end{array}$} & \multicolumn{2}{|c|}{$\begin{array}{l}95 \% \text { Confidence } \\
\text { Interval of the } \\
\text { Difference }\end{array}$} \\
\hline & & & & & & & & & Lower & Upper \\
\hline $\begin{array}{l}\text { analisis_ke } \\
\text { butuhan }\end{array}$ & $\begin{array}{l}\text { Equal variances } \\
\text { assumed }\end{array}$ & 2.302 & .135 & 505 & 58 & .616 & 1.25000 & 2.47760 & -3.70945 & 6.20945 \\
\hline & $\begin{array}{l}\text { Equal variances } \\
\text { not assumed }\end{array}$ & & & 541 & 45.819 & .591 & 1.25000 & 2.31225 & -3.40481 & 5.90481 \\
\hline
\end{tabular}

Berdasarkan hasil analisis pada Tabel 6. diatas di temukan nilai t hitung sebesar 0,505 sedangkan nilai $\mathrm{t}$ tabel sebesar 2,00, karena nilai $\mathrm{t}$ hitung $<\mathrm{t}$ tabel $(0,505<2,00)$ sehingga dapat disimpulkan menerima $\mathrm{HO}$ yang berarti bahwa tidak ada perbedaan pandangan antara mahasiswa dengan pandangan dosen terkait kebutuhan perangkat pembelajaran bahan ajar Sistem Rekayasa TV bahwa sama-sama sepakat bahwa memang sangat dibutuhkan.

Hal ini sejalan dengan pendapat Lee \& Owens, (2004: 181) bahwa Multimedia pembelajaran memanfaatkan fleksibilitas komputer untuk memecahkan masalahmasalah belajar. Sebagaimana kebanyakan sistem mengajar, komputer dapat digunakan sebagai alat mengajar terutama untuk memberi penguatan belajar awal, merangsang dan memotivasi belajar, atau untuk berbagai jenis kemungkinan lainnya. Banyak manfaat yang diperoleh dari fleksibilitas komputer karena dapat memasukkan video, audio, elemen-elemen grafis, bentuk-bentuk, proses, peran dan tanggungjawab lainnya Media berarti perantara/pengantar pesan dari pengirim ke penerima pesan. Dengan multimedia pesan ditampilkan melalui komputer sehingga user dapat melihat, mendengar, dan saling berinteraksi dan mengontrol media tersebut. Multimedia merupakan suatu sistem karena multimedia merupakan teknologi yang menggabungkan berbagai sumber media seperti teks, grafik, suara, animasi, video yang disampaikan dan dikontrol sistem komputer secara interaktif.

Nana Sudjana dan Ahmad Rivai (2002) menjelaskan ada beberapa keuntungan dalam mendayagunakan komputer dalam pembelajaran yaitu: (1) membangkitkan motivasi kepada siswa dalam belajar; (2) warna, musik grafis dan animasi dapat menambahkan kesan realism; menghasilkan penguatan yang tinggi; (4) kemampuan memori memungkinkan penampilan siswa yang telah lampau direkam dan dipakai dalam merencanakan langkah-langkah selanjutnya di kemudian hari; (5) berguna sekali untuk siswa yang lamban; (6) kemampuan daya rekamnya memungkinkan pengajaran individual dapat dilaksanakan, pemberian perintah secara individual dapat dipersiapkan bagi semua siswa terutama yang dikhususkan, dan kemajuan belajar pun dapat diawasi terus; (7) rentang pengawasan guru diperlebar sejalan dengan banyaknya informasi yang disajikan dengan mudah yang diatur oleh guru dan membantu pengawasan lebih dekat kepada kontak langsung dengan siswa.

Kemajuan media komputer memberikan beberapa kelebihan untuk kegiatan produksi audio visual. Pada tahun-tahun belakangan ini komputer mendapat perhatian besar karena kemampuannya yang dapat digunakan dalam bidang kegiatan pembelajaran termasuk pembelajaran mata kuliah manajemen produksi. Pembelajaran merupakan 
serangkaian kegiatan yang dirancang untuk memungkinkan terjadinya proses belajar pada pembelajar.

\section{KESIMPULAN}

Berdasarkan hasil analisis dan pembahasan maka dapat disimpulkan bahwa jumlah mahasiswa pada kategori sangat membutuhkan sebanyak 15 orang atau 35\%, Dibutuhkan 14 orang (32.5\%) dan pada kategori cukup juga sebanyak 12 orang $(32.5 \%)$.

Selanjutnya, hasil analisis berdasarkan kebutuhan berdasarkan pandangan oleh dosen pada kategori sangat dibutuhkan sebanyak 2 orang atau 10\%, Dibutuhkan 12 orang $(60 \%)$ dan pada kategori cukup sebanyak 6 orang (30\%).

Hasil Uji-t di temukan nilai $\mathrm{t}$ hitung sebesar 0,505 sedangkan nilai $\mathrm{t}$ tabel sebesar 2,00, karena nilai $\mathrm{t}$ hitung $<\mathrm{t}$ tabel $(0,505<2,00)$ sehingga dapat disimpulkan menerima $\mathrm{HO}$ yang berarti bahwa tidak ada perbedaan pandangan antara mahasiswa dengan pandangan dosen terkait kebutuhan perangkat pembelajaran bahan ajar Sistem Rekayasa TV bahwa sama-sama sepakat bahwa memang sangat dibutuhkan.

\section{DAFTAR PUSTAKA}

Borg ,W.R\& Gall,M.D. (2003). Educational Research: An Introduction. New York: Longman. Inc

Dani Darmawan. (2011) Teknologi Pembelajaran ( Bandung : PT Remaja Rosdakarya,)

Gerlach, V.S., \& Ely, D.P. (1979). Teaching \&media: a systematic approach (2nd ed.). Englewood Cliffs: Prentice-Hall Incorporated.

Hofstetter F.T. (2001). Multimedia literacy (3rd Ed.). New York: McGraw- Hill/Irwin.

Lee, W.W \& Owens, DL. (2004). Multimedia-Based Instructiononal Design Training Computer-Based, Distance Broadcast Training,
Performance Based Solution (2nd ). San Fransisco: Peiffera Wiley Imprin.

Mansyur. 2010. Membangun Sistem Assesmen yang Berkeadilan, Transparan dan Bermakna (Tinjauan dalam Proses Pendidikan). Pidato Disampaikan dalam rapat Senat Terbuka Luar Biasa UNM dalam Rangka Pengukuhan Guru Besar dalam Bidang Ilmu Penelitian dan Evaluasi Pendidikan. Makassar: Universitas Negeri Makassar.

Oetomo, Budi Sutedjo Dharma, S.Kom.,MM. 2002. e-Education Konsep, Teknologi dan Aplikasi Internet Pendidikan. Yogyakarta: Andi

Ramden, P. (2003) Learning to Teach in Higher Education. London: RoutledgeFalmer.

Robin dan Linda. (2001). Perkembangan Multimedia dan CD Interaktif (online) Tersedia http://www.http://macrobeni.Wor dpress.com/2008/11/5/perkemban gan-multimedia-CD interaktif.

Roblyer, M.D.; Castine, W.H.; and King, F.J. . (2000). Assesing the impact of computer based instruction: A review of recent research. (New York : Haworth Press., 2000

Smaldino Sharon E., Debaroh L. Lowther, and James D. (2008). Russel.Instructional Technology \& Media for Learning.Teknologi Pembelajaran dan Media untuk Belajar (Jakarta: Prenada Media Group.)

Suparman Atwi. (2004). Desain Instruktional (Jakarta: Universitas Terbuka.)

Suparman Atwi. (2012). Desain Instruktional Modern , Jakarta: Penerbit Erlangga . 